\title{
Honey and Human Wellness
}

\author{
Anisa M Durrani* \\ Department of Home Science, Aligarh Muslim University, India
}

Submission: February 20, 2018; Published: March 14, 2018

*Corresponding author: Anisa M Durrani, Professor, Department of Home Science, Aligarh Muslim University, India, Email: anisamd@gmail.com

\section{Introduction}

Honey is one of the most appreciated and valued natural product as a food as well as for its therapeutic attributes. Honey a natural sweetener, and is a versatile product that suits all occasions viz., religious ceremonies, spiritual functions, festival, at the time of birth, marriages and even death. Its significance is reinforced by the fact that, honey is considered food of foods, drink of drinks and drug of drugs. The traditional belief that honey is a mixture, a drug and an ointment is carried through generations and right into our lives [1]. Being a versatile product, it is used for creating appetite, strengthening the stomach, eliminating phlegm, as a meat preservative, hair conditioner. Eye sore, mouth wash and infected wounds healer and much more due to its antimicrobial properties [2]. The aim of this review is to emphasize the multi- dimensional utilitarian functions of honey and its multitude remedial medicinal aspects that meaningfully contributes to improve health conditions and well being of humankind from the beginning of civilization to the modern post millennium era.

Honey's efficacy as a tasty natural sweetener still remain unquestionable, it is nutritionally a high energy carbohydrate food considered to be the best source of heat and energy giving over 3200 calories $/ \mathrm{kg}$. Its quality of ensuring wholesome nourishment is credited to its energy-loaded contents. The energy value of one $\mathrm{kg}$ of honey is estimated to be approximately equal to 19 eggs, $3 \mathrm{~kg}$ milk, $6.5 \mathrm{~kg}$ plums, $3.5 \mathrm{~kg}$ greens, $5.5 \mathrm{~kg}$ apples or $7 \mathrm{~kg}$ carrots [3]. When consumed with milk its nutritious value gets multiplied and the combined attributes make it a complete diet .Merely adding honey can lead to improve the quality in a multitude of food products. Eatables like biscuits, cookies, cakes, nuts, fruits and saleds made with honey have pleasant flavour and are much more nutritious than many of sugar based products [4]. Other routine formulations such as bakery products [5], readyto-eat cereal [6,7], cookies [8], honey fruit spread [9], sweetened peanut butter spread [10], microwave cooked chicken patties with honey [11] and honey based ice creams [12] are examples of boosting nutrition. potency-cum-taste-enhancement.

\section{Composition of Honey}

Natural honey is essentially a concentrated aqueous solution of invert sugar, contains a very complex mixture of other carbohydrates, which contribute $95-97 \%$ of its dry weight. Fructose and glucose are two important sugars of honey which contributes most to its nutritional and physical effects. The other main compounds of honey include proteins with all nine essential amino acids and all nonessential amino acids except for asparagines and glutamine. Several enzymes, vitamins, minerals, and organic acids, aroma substances, pigments, waxes, pollen grains also are present in honey $[13,14]$. Pure Honey has antimicrobial and antifungal properties [1]. The honey do have an inane ability to restrain and control the growth of bacterial species such as Escherichia coli, Staphylococcus aurous, Salmonella typhimurium and Shigella. Its antimicrobial characteristics are due to presence of osmotic effect, acidity, $\mathrm{H}_{2} \mathrm{O}_{2}$, flavonoids polyphenols, anthraquinone reducing compounds, glycosides, alkaloids, cardiac glycosides, volatile compounds and aromatic acidic substances [15-17]. Flavonoids and polyphenols, which act as antioxidants, are two main bioactive molecules present in honey. Recent evidence shows that honey contain nearly thirty types of polyphenols $[18,19]$. The existence and levels of these polyphenols in honey can vary depending on the floral source, the climatic and geographical conditions. The ingredients of honey have been reported to exert antioxidant, antimicrobial, anti-inflammatory, anti proliferative, anticancer, and anti metastatic effects [20]. Studies have also revealed that honey can improve the medicinal potency as well as the quality in a variety of food products.

\section{Types of Honey}

There are approximately 300 types of recognised honey categories [21]. These varieties are related to different types of nectar that are collected by the honeybees. Honey is usually derived from the nectar of flowers and produced by bees. It is composed of a complex mix of sugars, amino acids, phenolics, and other substances. Honey types derived from different flowering 
plants vary substantially in their ability to kill bacteria, and this has complicated the literature on honey and made it sometimes difficult to reproduce results across different studies [22,23].

On the basis of the sources of sweet liquid and also the plant species in case of floral and extra floral nectar, the honey can be classified as floral honey or dew honey. It can also be categorized on the floral source such as Litchi honey, Berseem honey, Eucalyptus honey, Brassica honey etc. It is also very common to name the honey on the basis of its colour. Depending on the sucrose, honey can also be classified as natural honey and artificial honey. Natural honey is produced by honey bee while artificial honey is mostly inverted sucrose from beetroot or cane sugar and is produced with or without starch sugar or starch syrup. Artificial honey can be adjusted in appearance, odour and flavour to imitate the natural one [24].

\section{History of Honey}

The history of honey, honey- bees and usage of its products by mankind goes to time immemorial. Exactly how long honey has been in existence is hard to pin point because it fall back as far back as to the emergence of civilization record [25].

Its uses and production have a long and varied history recorded in cultural products. As an ancient activity, honey is depicted in cave paintings of human of Valencia, Spain at least 8,000 years ago [26,27]. Its 'magical' properties and versatility has given honey a significant part in history: Keeping bees in hives is a very ancient occupation. A record shows its traces in the sun temple of Cairo (2400BC). The bee featured frequently in Egyptian hieroglyphs. It often symbolised royalty. The ancient Egyptian used honey not only for sweetening but also as a gift for gods and as an ingredient for embalming their dead. The Greeks also made honey cakes and offered them to their gods. They used honey both as a food and as medicine. Similarly, ancient Romans use honey as a gift to god and for cooking sweet dishes. As a result bee keeping flourish widely in all ancient empires. With the onset of christianity honey and bee wax production increase manifold to meet the demand for church candles. Honey remained a popular sweetener in Europe until the Renaissance, when the sugar was discovered [25]. Conscious of its high value ancient Indians were also using honey as food and medicine. Chinese too used honey as superior medicine since its early civilization.

The Medicinal potential of honey is immense. Honey is non- irritant. It promotes rapid growth of healthy tissues and is useful in pruitus value, bed sores, skin and intestinal disorders. It is very commonly used in treatment of cough, cold, hay fever, gastro intestinal disorders. It also serves as an efficient energy drink which instantly replaces energy lost in various physical engagements.

\section{Medicinal History of Honey}

Several historical sources across civilizations shows that honey was commonly used for treatment of a number of ailments.
Stone Age paintings shows treatment of diseases with bee product well beyond 8000 years ago. Ancient scrolls, tablets and Sumerian clay tablets (6200 BC), Egyptian papyrus (1900-1250 BC), Veda (Hindu scripture) 5000 years, Bible, and Hippocrates (460-357 BC) illustrated that honey had been widely used as a drug [28-30]. Quran' eloquently depicts the therapeutic value of honey [31]. Even today in most of the medicinal domains honey is used for treating a variety of disease conditions, ranging from skin to hair falls, cardiology to neurology endochronoligical disorders to cancer and all kinds of chest diseases [31,32].

\section{Honey and Health}

Honey is always seen as an important means of improving the health conditions of human being through out eons. It is used not only as a nutritional product but also traditional medicine widely used it as an alternative treatment for a range of clinical conditions from wound healing to cancer treatment. Perhaps it is an universally unique nature based medicinal ingredient so commonly used in every civilization. Traditionally, honey is used in the treatment of most of the eye diseases, all kinds of bronchial asthma, throat infections and tuberculosis. other typical ailments that were treated include thirst, hiccups, fatigue, dizziness, hepatitis, constipation, worm infestation, piles and eczema. It is frequently used for healing of ulcers, and wounds and widely used as a nourishing supplement. The honey is reported to cause antioxidant, antimicrobial, antiinflammatory, anti proliferative, anticancer, and anti metastatic effects. Evidences also indicate that honey control and treat, diabetes, cancer, asthma, and wounds. It is also found effective in regulating and rectifying cardiovascular, neurological, and gastrointestinal problems. Its therapeutic potential is ascribed to the presence of phytochemical, anti-inflammatory, antimicrobial, and antioxidant properties. The existence of two medicinally valuable bioactive molecules flavonoids and polyphenols in honey, which act as antioxidants, substantially increases its therapeutical salience [33]. Contemporary researches also recognises honey's useful and its health oriented proactive effects that inhibits various disease. In conclusion, honey was and will continue to remain a vital natural ailment controlling and rectifying component as well as a significant remedy in a variety of health conditions in all the streams of health care, in every human communities spread across ages and geographies.

\section{References}

1. Mandal MD, Mandal S (2011) Honey: Its Medicinal Property and Antibacterial Activity. Asian Pac J Trop Biomed 1(2): 154-160.

2. Molen PC (1992) The antibacterial activity of honey; The nature of antibacterial activity. Bee World 73(1): 5-28.

3. Gopalan C, Rama Shastri BV, Balasubramanium SC (2004) Nutritive value of Indian foods. NIN, ICMR.

4. Singh N, Singh SJ, Bava AS, Sekhon KS (1988) Honey-Its food uses. Indian Food Pac.

5. Candert P (1971) Making long life bread. West German Patent Appl 2(012511). 
6. Fast RB, Hreschak BO, Spotts CE (1971) Honey-Graham Cereal. US Patent 3554: 763.

7. Colangelo K (1980) Combo packed yoghurt and granola gives convenience a healthy image. Dairy Field 163(10): 95-96.

8. Schmidt M (1978) Honey waffle. German Federal Republic Patent Application 2701765.

9. Berthold R, Benton AW (1968) Creamed honey-fruit spreads. Food Technol 22(1): 83-84.

10. Billerback FW, Everett LH, NcGowan PG, Pettinga PV (1976) Sweetened storage stable peanut spread and method of manufacture. United States Patent US4000322.

11. Naveena BM, Sen AR, Vaithiyanathan S, Muthukumar M, Babji Y, et al. (2007) Effect of honey and vitamin C on quality of microwave cooked chicken patties. J Food Sci Technol.

12. Saxena SK, Jaiswal V (2005) Wonders of golden liquid honey. Process Food Ind 8(10): 42-50.

13. Betts J (2008) The clinical application of honey in wound care. Nurs Times 104(14): 43-44.

14. El-Soud NHA (2012) Honey between traditional uses and recent medicine. Maced J Med Sci 5(2): 205-214.

15. White JW (1962) Composition of american honeys. Agricultural Research Service, USDA, Washington DC, USA.

16. White JW (1980) Detection of honey adulteration by carbohydrage analysis. J Assoc off Anal Chem 63(1): 11-18.

17. Islam A, Khalil I, Islam N, Moniruzzaman M, Mottalib A, et al. (2012) Physicochemical and antioxidant properties of Bangladeshi honeys stored for more than one year. BMC Complement Altern Med 12: 177.

18. Syazana NMS, Gan SH, Halim AS, Shah NS, Gan SH, et al. (2012) Analysis of volatile compounds of Malaysian Tualang (Koompassia excelsa) honey using gas chromatography mass spectrometry. Afr J Tradit Complement Altern Med 10(2): 180-188.

19. Carlos AU, David H, Carmen G (2011) Role of honey polyphenols in health. J Api Product Api Medical Sci.
20. Shamala TR, Jyothi YS (1999) Honey-It is more than just sweet. Indian Food Ind.

21. Lay-flurrie K (2008) Honey in wound care: Effects, clinical application and patient benefit. Br J Nurs 17(11): S30-S36.

22. Allen K, Molan P, Reid GA (1991) A Survey of the antibacterial activity of some New Zealand honeys. J Pharm Pharmacol 43(12): 817-822.

23. Irish J, Blair S, Carter D (2011) The antibacterial activity of honey derived from Australian flora. PLoS ONE 6(3): e18229.

24. Durrani A, Srivastava PK, Verma S (2011) Processing and Utilization of Honey and It's Products. Process Food Industry.

25. BHIPA (2017) A Brief History of Honey. The Honey Association, British Honey Importers and Packers Association.

26. Hunt CL, Atwater HW (2015) Honey and its uses in the Homes. US Department of Agriculture, Farmers 'Bulletin, No. 653. The Archaeology of Beekeeping.

27. Eva Crane (2011) Duckworht 1983 Original form. University of Minnesota. Digitized. Edition illustrated Publisher, New York, USA.

28. Mijanur RM, Gan SH, Khalil MI (2014) Neurological effects of honey: Current and future prospects. Evid Based Complement Alternat Med 2014: 958721.

29. Newman TG (1983) Honey Almanac. IL: Newman, Chicago, USA.

30. Molan PC (2001) The potential of honey to promote oral wellness. Gen Dnt 49(6): 584-589.

31. Bergman A, Yanai J, Weiss J, Bell D, David MP, et al. (1983) Acceleration of wound healing by topical application of honey. An animal model. Am J Surg 145(3): 374-376.

32. Irving TB, Ahmad K, Ahsan MM (1987) The Qur'an-Basic Teachings. The story of creation. Chapter 5, Bath: Pitman Press, UK.

33. Samarghandian S, Farkhondeh T, Samini F (2017) Honey and Health: A Review of Recent Clinical Research. Pharmacognosy Res 9(2): 121-127.

Your next submission with Juniper Publishers will reach you the below assets

- Quality Editorial service

- Swift Peer Review

- Reprints availability

- E-prints Service

- Manuscript Podcast for convenient understanding

- Global attainment for your research

- Manuscript accessibility in different formats

( Pdf, E-pub, Full Text, Audio)

- Unceasing customer service

Track the below URL for one-step submission https://juniperpublishers.com/online-submission.php 